\title{
TOURIST POVERTY AS A CULTURAL AND HUMANITARIAN DETERMINANT
}

\author{
Печенюк А.П., \\ канд. екон. наук, докторант, \\ Подільський державний аграрно-технічний університет
}

\section{ТУРИСТИЧНА БІДНІСТЬ ЯК КУЛЬТУРНО-ГУМАНІТАРНА ДETEPMIHAHTA}

Formulation of the problem. The concept of neoliberalism, which is used by many countries around the world, generates significant benefits for big business and is aimed at maximizing profits.

At one time, this made the whole world believe in the victory over poverty, provided that all countries embark on liberal reforms, the essence of which is the openness of national economies, the complete privatization of state property, free trade and the absence of state protectionism for individual industries. For a long time it was believed that these reforms are positive and meet the requirements of globalization, which is beneficial for all countries. However, it is worth noting that not all states were able to take advantage of globalization, which led to an even greater gap and deepening social inequality between rich and poor, the essence of which is determined not only by material, but also by humanitarian aspects.

A characteristic feature of Ukrainian realities is the intensification of socio-economic transformations, which leads to a change in established patterns of socio-economic behaviour of the population and the development of social inequality. The problem of poverty in general is extremely acute for Ukraine. Of course, the decline in household income and the lack of confidence in tomorrow have a negative impact on the overall state of tourism in the country, in particular, on domestic tourism consumption, which leads to a decrease in revenues from the tourism sector. We associate this situation with the phenomenon of tourist poverty of the population. Unfortunately, modern science does not give clear definitions about the defined definition, there are no clear criteria for its measurement, and most importantly, the problem of its overcoming not only in our country, but also on a global scale, is still unresolved.

Analysis of recent research and publications. The issue of population poverty is explored in the writings of Holota A. - from the standpoint of analytical evaluation of the main approaches to definition; Hnatkovych O. explores tourist poverty and ways to overcome it in Ukraine; Kharchenko N. explores poverty from the standpoint of sociological analysis; in the writings of Valevskyi O., the sphere of culture is defined as a component of the formation of social consolidation of the state. Considering the existing theoretical framework, we believe that the issue of tourist poverty of the population today requires in-depth research and improvement of methodological tools, which led to the choice of topic.

Setting objectives. The purpose of our study is to deepen and complement the theoretical aspects of the study of tourist poverty. The following tasks were solved: generalization of theoretical aspects on the chosen topic; definition of tourist poverty and its causes from the point of view of cultural and educational development of citizens; developing proposals to avoid tourism poverty and reduce its negative impact.

Outline of the main research material. The liberalization of the economy, which was aimed at establishing capitalist relations, led to a complete change in the structure of Ukrainian society, which was manifested by its considerable polarization and social inequality, a sign of which is poverty.

Currently, the following approaches to determining and assessing poverty are common: absolute; relative; subjective; integral (Fig. 1). Each approach has certain features and calculated indicators, but, unfortunately, none of these approaches reflects the comprehensive scope and essence of the phenomenon under study.

Hnatkovych O. [2], in order to explain the reasons for the low level of domestic tourism development in Ukraine, among other arguments cites the tourist poverty of the population, which is determined by the economic determinants. Consistent with his individual views, we believe that this category should be considered not only in the material plane, but also from the standpoint of cultural and humanitarian development of our citizens. To substantiate our opinion, we use the data of the State Statistics Service of Ukraine on tourist flows of our country (Table 1). 


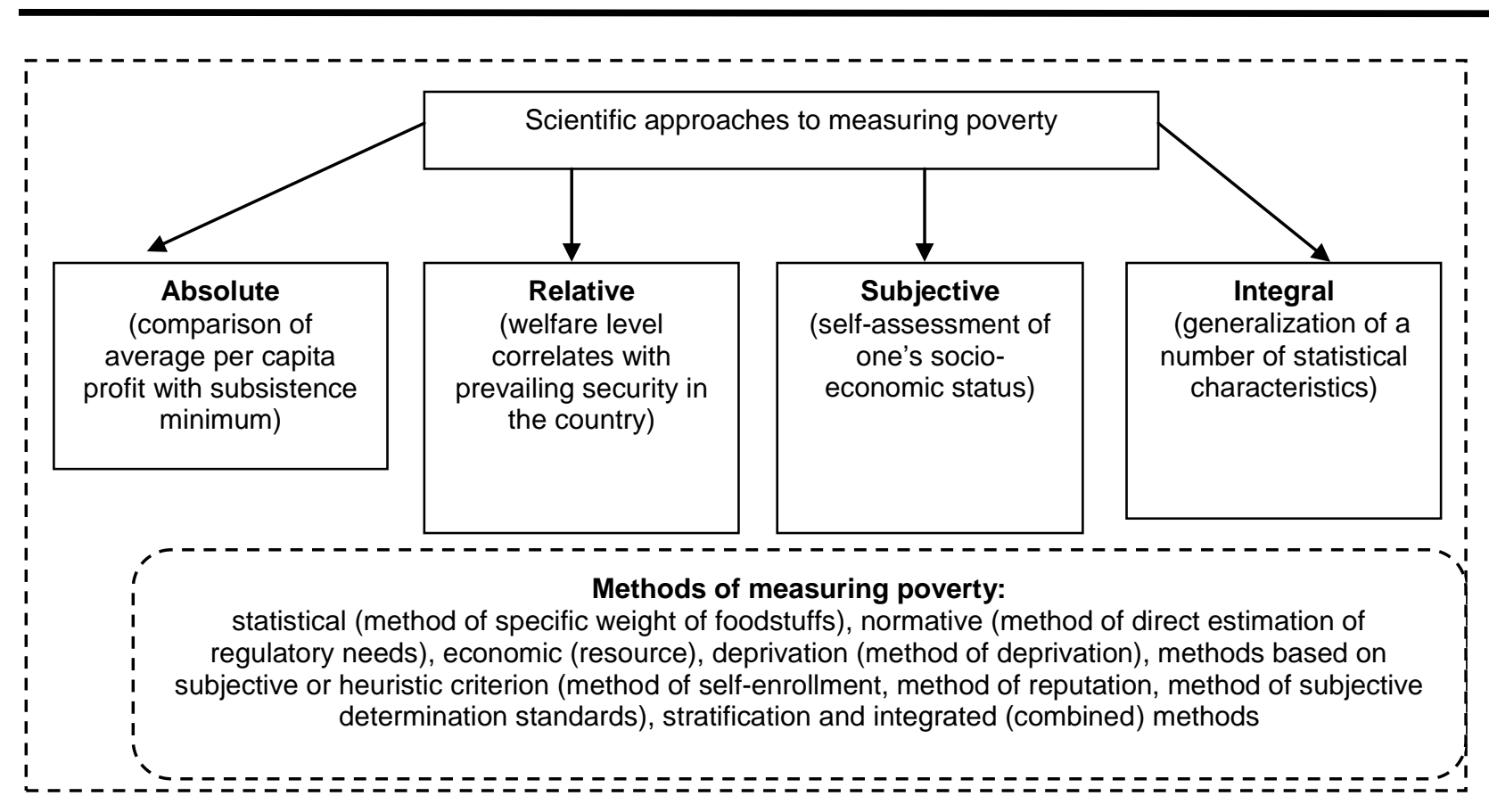

Figure 1. Basic approaches to measuring poverty

Source: compiled by the author on the basis of [1].

Tourist flows of Ukraine, thousand people

Table 1

\begin{tabular}{|c|c|c|c|c|c|c|c|c|c|c|c|}
\hline $\begin{array}{c}\text { Number of } \\
\text { tourists }\end{array}$ & 2009 & 2010 & 2011 & 2012 & 2013 & 2014 & 2015 & 2016 & 2017 & 2018 & $\begin{array}{c}\text { Deviatio } \\
\text { n 2018 } \\
\text { from } \\
2009 \%\end{array}$ \\
\hline Away & 913,6 & 129,6 & 125,1 & 195,7 & 251,4 & 208,3 & 1647,4 & 2060,0 & 2289,8 & 4024,7 & 440,5 \\
\hline Internal & 1094,2 & 649,3 & 715,6 & 774,0 & 702,6 & 322,7 & 357,0 & 453,6 & 477,0 & 456,8 & 41,7 \\
\hline
\end{tabular}

Source: calculated by the author on the basis of data provided by the State Statistics Service of Ukraine [3].

According to statistics, in recent years there has been a significant increase in tourist flows from Ukraine and a decrease in the number of tourists who took advantage of the offers of Ukrainian participants in the tourist market. The end of 2018 for outbound tourists shows an increase of more than four times compared to 2009. This situation has a negative impact on the development of domestic tourism and again proves that the problem should be sought not only in material aspects, but also in cultural and humanitarian ones.

Restraining factors of systemic reforms in our country in general and in rural areas in particular are not only material factors, but also outlook and behavioral attitudes of the population (Table 2). In a broad sense, it is about cultivating a subculture of poverty that is known to have the potential for self-reproduction and, in certain circumstances, becomes the style and way of life of some citizens of the country. The culture of the tourist poverty of the population is shaped by both the structural determinants and the subjective feelings of the people, which are determined by the degree of satisfaction of the individual with the level of material and humanitarian development.

\section{Material and outlook (humanitarian) traits of tourist poverty}

Table 2

\begin{tabular}{|l|l|}
\hline \multicolumn{1}{|c|}{ Material characteristics } & \multicolumn{1}{c|}{ Outlook (humanitarian) characteristics } \\
\hline Financial problems, low income & Low level of education \\
\hline Absence of stable financial income & Low levels of social, economic and cognitive activity \\
\hline Lack of opportunities for savings & Lack of motivation to travel \\
\hline The social nature of tourist consumption & Formation of indifference to tourist consumption \\
\hline Difficult economic and political situation in the country & Absence of a national state policy of cultural development \\
\hline
\end{tabular}

Source: author development 
The reasons for the emergence of tourist poverty of the population can be explained on the basis of the following approaches: individualistic, based on the personal characteristics of the consumer of the tourist product, his inquiries, lifestyle, income, sphere of interest, outlook; in the structural approach, responsibility for tourism poverty rests on a society that is recognized as structurally imperfect in terms of social, economic and political development. In a fatalistic understanding of the causes of the tourist poverty of the population, the fault relies on factors that are independent of the individual: circumstances, the presence or absence of talents, obstacles to life, etc. When using the subcultural approach, the main focus is the view that poverty is a hereditary phenomenon that shapes the psychology of tourist poverty [1].

Tourist poverty involves the use of an adaptation strategy, which is characterized by significant savings in the intangible sphere of the individual's life and complete abandonment of tourist activity.

This may result in tourism marginalization - a process of decline in tourist activity due to economic and humanitarian factors, characterized by an increase in the number of citizens who do not participate in tourist activities, are socially passive, do not position themselves with certain social groups, without clear or identifiable identities for tourism interests that are included in tourist consumption through public funds.

The reasons for the spread of marginalization among the population are the changes that lead to the destruction of traditional social institutions (economic crises, wars, revolutions, etc.), the inability of the economic system to create enough jobs for those wishing to work, the presence in the society of citizens who, due to certain socio-psychological physiological characteristics are not capable or unwilling to work or use tourist offers [4].

Humanitarian development, in particular the enhancement of citizens' cultural competences, has considerable consolidating potential. The cultural competence of an individual indicates the degree of his or her socialization and integration into society, which gives understanding and application of knowledge, rules of behaviour, as well as, systems of attitudes and values that ensure the integrity of cultural space. Cultural competence indicates that the individual has the necessary knowledge and skills, as well as the capacity for personal growth through the acquisition of cultural heritage and values [5].

The main problems of forming the cultural competence of citizens are considered in Table 3.

Problems of cultural competence formation in Ukraine

Table 3

\begin{tabular}{|c|c|}
\hline Kind of a problem & Features \\
\hline Distortion of historical memory & $\begin{array}{l}\text { The presence of a long-lasting conflict and struggle for historical truth } \\
\text { in a society. }\end{array}$ \\
\hline Differences in vision of culture in the country & $\begin{array}{l}\text { It manifests itself in the polarization of society from the desire to adopt } \\
\text { Western European approaches to ethnic Ukrainian nationalism on the } \\
\text { one hand, and a return to values upheld by the Soviet Union on the } \\
\text { other. }\end{array}$ \\
\hline Slow shifts in society & $\begin{array}{l}\text { Difficulties in overcoming post-Soviet (or post-colonial) syndrome in } \\
\text { the formation of national cultural identity. }\end{array}$ \\
\hline $\begin{array}{l}\text { Tendency to hypothetically uphold European } \\
\text { values, but selectively translate them into } \\
\text { everyday practice }\end{array}$ & $\begin{array}{l}\text { Basic European values are enshrined in the } 2007 \text { Lisbon Treaty. It is } \\
\text { respect for human dignity, freedom, democracy, equality, the rule of } \\
\text { law, respect for human rights. The Charter of the European Union on } \\
\text { Human Rights sets out the following values that are common to the } \\
\text { EU Member States: the protection of human and civil rights and } \\
\text { freedoms, equality, solidarity, democracy, the rule of law. }\end{array}$ \\
\hline $\begin{array}{l}\text { Insufficient level of educational competence } \\
\text { of citizens }\end{array}$ & $\begin{array}{l}\text { According to the Organization for Economic Co-operation and } \\
\text { Development's rating on the quality of school education, Ukraine } \\
\text { ranked 38th out of } 76 \text { countries that participated in the study. }\end{array}$ \\
\hline Destruction of cultural space & $\begin{array}{l}\text { According to the results of a sociological survey on the functioning of } \\
\text { the infrastructure of cultural institutions, during the last year most } \\
\text { citizens ( } 60 \% \text { ) did not read books (electronic or printed) and did not } \\
\text { visit the library at all; } 50 \% \text { of Ukrainian adults have not attended any } \\
\text { cultural events in the past year; only } 1 \% \text { of the population attend } \\
\text { cultural events as often as they wish; } 50 \% \text { of respondents say they } \\
\text { would attend cultural events more often if they had more money; } 17 \% \\
\text { of respondents said that there is no opportunity for creative and } \\
\text { artistic development of children in their locality. }\end{array}$ \\
\hline $\begin{array}{l}\text { Insufficient level of information competence } \\
\text { of citizens }\end{array}$ & $\begin{array}{l}\text { With the development of electronic media, information-rich and } \\
\text { information-poor people are emerging, information and electronic } \\
\text { "gaps" are deepening, and electronic illiteracy is widespread. }\end{array}$ \\
\hline
\end{tabular}

Source: compiled by the author on the basis of [5; $6 ; 7 ; 8]$

The impact of these factors leads to the threat of loss of educational and cultural competences for the population. Undoubtedly, the lack of cultural competence of the citizens of the country contributes to the spread of tourist poverty. 
In this sense, we can cite the concept of a "poverty culture", which distinguishes four main features: low participation and critical attitude towards all public institutions; minimum level of organization; different from generally accepted norms of relationship; overcoming helplessness, compromise, dependence, humiliation, low motivation; orientation exclusively on the present, inability to plan [4].

For the sake of completeness, it should be recognized that tourism poverty can be viewed from two aspects: from the consumer's point of view and from that of the tourist industry. Recently, the poor of tourism in countries with low levels of development have become quite a popular tourist attraction. For example, among the consumers of the tourist product (USA, UK and Australia), according to the tourist operators, the most popular tourist route in India is the Dharavi deep-sea excursion, which in popularity is even higher than the visit to the Taj Mahal. Dharavi is located in the largest city of India - Mumbai, with a million people living in dire conditions.

India has only recently joined this tourism trend. For example, Brazil and South Africa have been practicing such treks in the wild for a long time. Tour operators say that what tourists see can change their attitude to life in the wilds.

It is worth noting that cultural competence, as recommended by the European Parliament and the Council (EU), is included in the eight core competences that citizens need for active social life, personal fulfilment, development and social cohesion. The cultural competence of the citizens of our country can be adapted to tourism activities. Undoubtedly, the higher the level of competence development, the wider knowledge of local, national and European cultural heritage and its place in the world, the understanding of cultural and linguistic aspects, the skills to identify and realize social and economic opportunities in tourism, the less chance is left to form prerequisites the emergence and spread of tourist poverty.

Against this background, the main tasks of cultural development should be manifested in the formation of the basis of social consolidation and overcoming of tourist poverty.

The causes of cultural deconsolidation of society and tourist poverty can be grouped into the following areas:

1. Infrastructure - manifested in the destruction of the infrastructure of cultural institutions, which led to the inaccessibility of cultural goods to the general population and the spread of poverty;

2. Cultural - manifested by the destruction of the cultural competences of citizens, the replacement of cultural values;

3. Educational - determined by the destruction of cultural education and the marginalization of cultural activity in depressed regions and rural territories;

4. Economic - determined by the weak financial and material base of cultural institutions;

5. Motivational - manifests economic and social unattractiveness of cultural work.

In order to enhance the unity in society and overcome the humanitarian and cultural tourist poverty, problems and challenges that arise today, it is necessary to: form in society common world outlook, understanding of historical aspects of the country's development, dissemination of information about traditions, customs, features of other regions of the country; raise the general cultural and educational level of the population in order to exclude propaganda, stereotypes, provocations; educate young people to respect traditions, culture, history, language, national symbols and customs; to develop the cultural competences of citizens regardless of their place of residence [5].

Conclusion. Tourist poverty should be considered not only in the material plane but also in terms of cultural and humanitarian development of our citizens. According to the data of the State Statistics Service of Ukraine, the tourist consumption of imported tourism product by citizens of our state has more than quadrupled over the past ten years, which raises some doubts about considering tourism poverty only from the standpoint of financial support for our citizens.

In this sense, one can cite the concept of a "poverty culture" that produces material poverty. In general, the higher the level of cultural competence of citizens, the lower the level of tourist poverty. The consequence of tourist poverty is the tourist marginalization of the population, which does not contribute to the material or moral development of a person.

In order to avoid tourist poverty, common world outlook should be formed in society, the general cultural and educational level of the population should be raised; nurture respect for national symbols and traditions; to develop general cultural competences of citizens. We see further research prospects in identifying specific indicators that would indicate the effectiveness of cultural work aimed at avoiding the phenomenon of tourist poverty.

\section{Література}

1. Голота А. С. Основні підходи до вивчення бідності у контексті сімейної взаємодії. 2012. URL: http://lib.iitta.gov.ua/9170/1/ОСНОВНІ\%20ПІДХОДИ\%20ДО\%20ВИВЧЕННЯ\%20БІДНОСТІ\%20У\%20КОН ТЕКСТІ\%20СІМЕЙНОї\%20ВЗАЄМОДІї.рdf (дата звернення: 26.10.2019).

2. Гнаткович О. Д. Подолання туристичної бідності в Україні. Економіка і суспільство. 2017. Вип. 9. C. 176-208. URL: http://economyandsociety.in.ua/journal/9_ukr/30.pdf (дата звернення: 02.10.2019). 
3. Кількість туристів, обслугованих туроператорами та турагентами, за видами туризму. Державна служба статистики. URL: https://ukrstat.org/uk/operativ/operativ2007/tyr/tyr_u/potoki2006_u.htm (дата звернення: 01.10.2019).

4. Харченко Н. Різноманітність аспектів бідності: спроба соціологічного аналізу. Наукові записки. 1999. Том 7. Політологія, соціологія. С. 38-49. URL: https://kiis.com.ua/materials/articles/poverty.pdf (дата звернення: 09.10.2019).

5. Валевський О. Л. Функції культури у формуванні суспільної консолідації України. Аналітична записка. Серія «Гуманітарний розвиток». 2019. № 1. С. 15.

6. Норріс Л., Ланкеліне В. Доповідь про розвиток сектору культурної спадщини в Україні. URL: https://www.culturepartnership.eu/upload/editor/2017/Subsector_report_Ua_ukrainian_Fin.pdf (дата звернення: 24.10.2019).

7. Печенюк А.П. Реалізація національної етнокультурної компоненти сільського туризму в умовах глобалізаційних викликів. Бізнес Інформ. 2019. № 9. С. 57-62. https://doi.org/10.32983/22224459-2019-9-57-62.

8. Овчаренко С. В. Гуманітарна та культурна політика : навч. посіб. Одеса : ОРІДУ НАДУ, 2013. 152 c. URL: http://www.oridu.odessa.ua/9/buk/ovcharenko.pdf (дата звернення: 04.10.2019).

\section{References}

1. Holota, A.S. (2012), "Basic approaches to the study of poverty in the context of family interaction", available at: http://lib.iitta.gov.ua/9170/1/OSNOVNI\%20PIDKhODY\%20DO\%20VYVChENNIa\%20 BIDNOSTI\%20U\%20KONTEKSTI\%20SIMEINOI\%20VZAleMODII.pdf (access date October 26, 2019).

2. Hnatkovych, O.D. (2017), "Overcoming tourist poverty in Ukraine", Ekonomika $i$ suspilstvo, Iss. 9, pp. 176-208, available at: http://economyandsociety.in.ua/journal/9_ukr/30.pdf (access date October 02, 2019).

3. Derzhavna sluzhba statystyky (2018), "Number of tourists served by tour operators and travel agents by type of tourism", available at: https://ukrstat.org/uk/operativ/operativ2007/ tyr/tyr_u/potoki2006_u.htm (access date October 01, 2019).

4. Kharchenko, N. (1999), "Diversity aspects of poverty: An attempt at sociological analysis", Naukovi zapysky. Vol. 7. Politolohiia, sotsiolohiia, pp. 38-49, available at: https://kiis.com.ua/materials/ articles/poverty.pdf (access date October 09, 2019).

5. Valevskyi, O.L. (2019), "The functions of culture in forming Ukraine's social consolidation", Analitychna zapyska. Seriia "Humanitarnyi rozvytok", no. 1, pp. 15.

6. Norris, L. and Lankeline, V. (2017), "Report on the development of the cultural heritage sector in Ukraine", available at: https://www.culturepartnership.eu/upload/editor/2017/Subsector_report_Ua_ ukrainian_Fin.pdf... (access date October 24, 2019).

7. Pecheniuk, A.P. (2019), "Implementation of the national ethno-cultural component of rural tourism in the face of globalization challenges", Biznes Inform, no. 9, pp. 57-62, https://doi.org/10.32983/2222-44592019-9-57-62.

8. Ovcharenko, S.V. (2013), Humanitarna ta kulturna polityka [Humanitarian and cultural policy], tutorial, ORIDU NADU, Odesa, Ukraine, 152 p., available at: http://www.oridu.odessa.ua/9/buk/ovcharenko.pdf (access date October 04, 2019). 